\title{
ANALISIS FAKTOR INTERNAL DAN EKSTERNAL PERUSAHAAN TERHADAP HARGA SAHAM SEKTOR CONSUMER GOODS INDUSTRY DI BURSA EFEK INDONESIA (BEI)
}

\author{
Syahril Effendi $^{1)^{*}}$, Baru Harahap ${ }^{2)}$ \\ ${ }^{1}$ Fakultas Ilmu Sosial dan Humaniora, Prodi Akuntansi, Universitas Putera Batam \\ email: syahril@puterabatam.ac.id \\ ${ }^{2}$ Fakultas Ilmu Sosial dan Humaniora, Prodi Akuntansi, Universitas Putera Batam \\ email: $\underline{\text { baru@puterabatam.ac.id }}$
}

\begin{abstract}
This study aims to determine the effect of a given return on equity, earnings per share, Inflation and Interest Rates on Stock Prices on the company's sector of consumer goods industry listed on the Indonesia stock Exchange. The population in this study consisted of 49 companies engaged in the sector of consumer goods industry listed in Bursa efek Indonesia (BEI). Sampling technique in this study using purposive sampling and there are 10 companies that meet the criteria for the selection of the sample. Financial Data in this research was obtained through IDX representative of Kepri. As for the inflation data and the interest rate is obtained from Central bureau of Statistics and Bank Indonesia. The research results of the F test show a significant influence of the mean return on equity, earnings per share, inflation and interest rates simultaneously have a significant influence on stock prices so that the regression model contained in this study deserve to be studied. Partially by t test obtained the result that variable return on equity and earnings per share have a significant effect on stock prices, while variable inflation and interest rates do not significantly influence the stock price.
\end{abstract}

Keywords: Return on Equity; Earning per Share; Inflation; Interest Rate; Stock Price.

\begin{abstract}
ABSTRAK
Penelitian ini bertujuan untuk mengetahui pengaruh yang diberikan laba atas ekuitas, laba per lembar saham, Inflasi dan Suku Bunga terhadap Harga Saham pada perusahaan sektor consumer goods industry yang terdaftar di Bursa Efek Indonesia. Populasi dalam penelitian ini terdiri dari 49 perusahaan yang bergerak di bidang sektor consumer goods industry yang terdaftar di Bursa Efek Indonesia (BEI). Teknik penentuan sampel dalam penelitian ini menggunakan purposive sampling dan terdapat 10 perusahaan yang memenuhi kriteria pemilihan sampel. Data keuangan dalam penelitian ini di peroleh melalui IDX perwakilan Kepri. Sedangkan untuk data inflasi dan suku bunga ini di peroleh dari Badan Pusat Statistika dan Bank Indonesia. Hasil penelitian uji F menunjukkan terdapat pengaruh signifikan yang berarti laba atas ekuitas, laba per lembar saham, inflasi dan suku bunga secara simultan memberikan pengaruh yang signifikan terhadap harga saham sehingga model regresi yang terdapat dalam penelitian ini layak untuk diteliti. Secara parsial melalui uji $t$ diperoleh hasil yaitu variabel laba atas ekuitas dan laba per lembar saham berpengaruh signifikan terhadap harga saham, sedangkan variabel inflasi dan suku bunga tidak berpengaruh secara signifikan terhadap harga saham.
\end{abstract}

Kata Kunci: Laba atas ekuitas, Laba per lembar saham, Inflasi, Suku Bunga, Harga saham. 


\section{PENDAHULAN}

Di Indonesia, persaingan untuk bisnis semakin meningkat dengan munculnya berbagai bidang bisnis seperti industri, perdagangan dan jasa. Salah satunya di industri barang konsumsi. Untuk alasan ini, masingmasing perusahaan diharuskan untuk bersaing secara adil dalam upaya untuk mematahkan pangsa pasar domestik dan global untuk mencapai omset yang diharapkan. Untuk mendapatkan sumber dana atau dana tambahan, Perusahaan mendaftarkan langganan publik di pasar modal. Pasar modal merupakan lokasi berkumpulnya perusahaan dalam kegiatan penjualan saham dan obligasi yang bertujuan mendapatkan dana untuk modal perusahaan (Fahmi, 2015).

Selama 5 tahun terakhir, dimulai dari tahun 2013-2017 total harga saham perusahaanperusahaan sektor consumer goods industry mengalami penurunan yang cukup drastis dari tahun 2013 sebesar Rp 2.009.034 menjadi Rp 841.842 di tahun 2014, pada tahun 2015 menurun sebesar Rp 514.490 sehingga menjadi Rp 327.352 dan 2016 mengalami penurunan lagi menjadi Rp 229.394. Namun pada tahun 2017 mengalami kenaikan sebesar Rp 41.588 sehingga menjadi Rp 270.982. Di dunia saham, ada dua faktor yang menyebabkan kenaikan atau penurunan harga saham, baik faktor internal maupun eksternal.

Menurut Dewi \& Vijaya (2017) Faktor internal adalah faktor yang menyebabkan harga saham naik atau turun karena situasi perusahaan sendiri, seperti perubahan dewan, kinerja keuangan perusahaan, dan masalah hukum yang melibatkan manajer atau karyawan perusahaan. Sedangkan faktor eksternal adalah faktor yang menyebabkan harga saham lebih tinggi atau lebih rendah yang berada di luar kendali perusahaan, seperti kebijakan pemerintah, kondisi makroekonomi, risiko sistemik, dan efek psikologi pasar. Penelitian sini bertujuan untuk mengetahui pengaruh return onsequity, earning pershare, inflasi dan suku bunga terhadap harga saham sektor consumer goods industry di Bursa Efek Indonesia

\section{KAJIAN LITERATUR}

Pendanaan meletakkan sekumpulan uang yang ada dengan harapan menerima laba di masa depan (Gusti \& Vijaya, 2017). Pasar modal adalah tempat bagi berbagai pihak terutama perusahaan) untuk menjual saham (stock) dan obligasis (bond), Hasil penjualan dapat dipergunakan sebagai dana tambahan satau modal perusahaan yang ditingkatkan (Fahmi, 2015). IPO atau sering disebut sebagai penawaran umum adalah aktivitas penyajian saham oleh perusahaan kepada publik, dengan menawarkan saham kepada publik, agensi yang terdaftar di bursa publik / terbuka perusahaan, sehingga memudahkan perusahaan untuk mendapatkan modal untuk memenuhi kebutuhan modal mereka atau meningkatkan citra perusahaan (Dewi \& Vijaya, 2017). Menurut Sutedi (2013) saham adalah property dari suatu kekayaan dan salah satu jeroan atau agen.

Menurut David (2010) mengartikan harga saham adalah citra dalam penilaian kinerja perusahaan. Perusahaan yang memiliki kinerja baik, harga saham perusahaan memiliki nilai tinggi. Saham yang menarik bagi investor membuat saham melebihi penawaran mereka, menyebabkan harga saham naik. Demikian pula, jika kinerja perusahaan lemah, itu akan berdampak pada harga ekuitas yang lebih rendah.

Menurut Fahmi (2015) mengartikan return onsequity adalah rasio menguji sejauh mana perusahaan menggunakan sumber dayanya untuk dapat memberikan pengembalian atas ekuitas. Menurut Fahmi (2015) mengartikan earning persshare adalah bentuk pemberian manfaat yang diberikan kepada pemegang saham di setiap kertas yang dimiliki oleh perusahaan.

Menurut Boediono (2014) suku bunga adalah biaya yang harus dibayar peminjam untuk pinjaman yang diterima adalah bonus bagi pemberi pinjaman. Sedangkan menurut Fahmi (2015) inflasi adalah suatu peristiwa yang menggambarkan situasi harga barang yang mengalami kenaikan dan devaluasi mata uang.

Hasil penelitian Widiastuti et al (2016) menunjukkan bahwa Current Ratio, Debt to Equity Ratio, Return On Equity, Earning Per 
Share, Inflasis, dan Tingkat Suku Bunga secara bersamaan memiliki dampak signifikan pada harga saham. Selanjutnya penelitian yang dilakukan oleh Dewi \& Artini (2016) menunjukkan bahwa EPS dan ROE efek positif sebagian penting untuk harga saham, sedangkan variabel suku bunga SBI, inflasi, dan debt to equity ratio (DER) Secara parsial tidak ada dampak signifikan pada harga saham.

Berdasarkan uraian diatas, kerangka pemikiran yang digunakan untuk merumuskan hipotesis tentang pengaruh faktor internal dan eksternal_perusahaan terhadap_harga saham ini dapat digambarkan sebagai berikut:

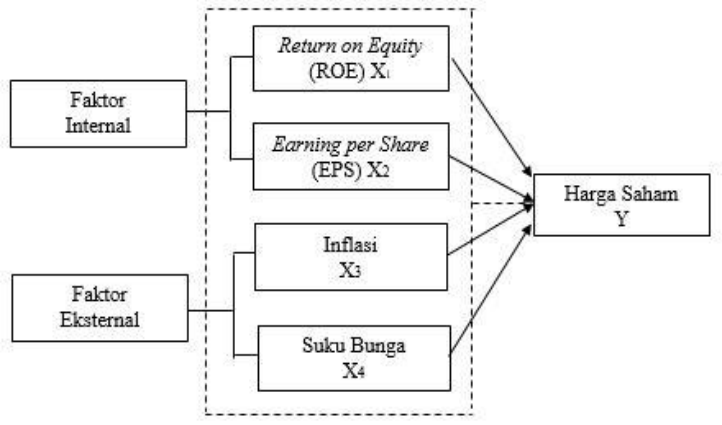

Gambar 1. Kerangka Pemikiran

Hipotesis dalam penelitian ini adalah:

$\mathrm{H}_{1}$ :Return on Equity berpengaruh signifikan terhadap harga saham sektor consumer goods industry di Bursa Efek Indonesia.

$\mathrm{H}_{2}$ :Earning per Share berpengaruh signifikan terhadap harga saham sektor consumer goods industry di Bursa Efek Indonesia.

$\mathrm{H}_{3}$ :Inflasi berpengaruh signifikan terhadap harga saham sektor consumer goods industry di Bursa Efek Indonesia.

$\mathrm{H}_{4}$ :Suku Bunga berpengaruh signifikan terhadap harga saham sektor consumer goods industry di Bursa Efek Indonesia.

$\mathrm{H}_{5}$ :Return on Equity, Earning per Share, Inflasi dan Suku Bunga berpengaruh signifikan terhadap harga saham sektor consumer goods industry di Bursa Efek Indonesia.

\section{METODE PENELITIAN}

Penelitian ini bertujuan untuk menguji pengaruh ROE, EPS, Inflasi dan Suku Bunga terhadap Harga Saham. Variabel dependen dalam penelitian ini adalah harga saham. Variabel ini diukur dengan closing stock price. Variabel independen dalam penelitian ini adalah Return on Equity, Earning per Share, Inflasi dan Suku Bunga. Populasi dalam penelitian ini adalah perusahaan sektor consumer goods industry yang terdaftar di Bursa Efek Indonesia yang berjumlah 49 perusahaan. Metode pengambilan sampel dalam penelitian ini adalah menggunakan metode purposive sampling dan memperoleh 10 perusahaan yang memenuhi kriteria.

Teknik pengumpulan data dalam penelitian ini adalah dokumentasi dan studi kepustakaan (library research). Data dalam bentuk data digital diperoleh dari laporan keuangan tahunan perusahaan sektor industri barang konsumsi yang terdaftar di Bursa Efek Indonesia sedangkan untuk data inflasi dan suku bunga diperoleh dari website Bank Indonesia. Data yang dikumpulkan dalam penelitiansini dianalisis dengan aplikasi SPSS (Statistical Package for the Social Science) versi 24. Metode analisis dalam penelitian ini adalahsanalisis regresi linier berganda dengan melakukan uji statistik deskriptif, uji asumsi klasik dan pengujian hipotesis yang terdiri dari uji-t, uji-F. Penelitian ini dilakukan di perusahaan sektor consumer goods industry yang terdaftar di BEI yang berlokasikan di Komplek_Mahkota_Raya No. 11 Blok A Batam Center, Kota Batam, Kepulauan Riau, Indonesia.

\section{HASIL DAN PEMBAHASAN}

\section{Uji Asumsi Klasik}

\section{Uji Normalitas}

Uji normalitas berfungsi untuk memahami model regresi variabel varian, yang memiliki distribusi normal (Ghozali, 2016).

Tabel 1. Hasil dari One-Sample KolmogorovSmirvnov Test

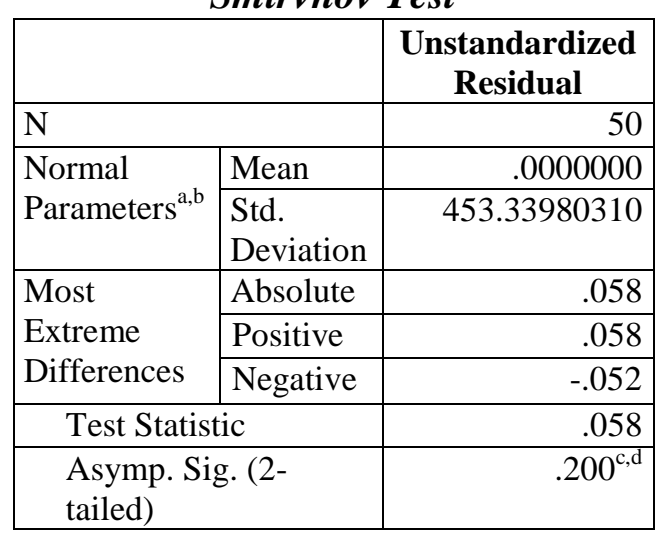


Melihat tabel 1 diatas, dapat dilihat nilai Asymp. Sig. (2-tailed) sebesar 0,200 sehingga dapat diasumsikan bahwa data didistribusikan secara normal. ini karena tingkat signifikansi Asymp. Sig. (2-tailed) 0,200 > 0,05.

\section{Uji Multikolonieritas}

Uji multikolinieritas berfungsi untuk menemukan hubungan antara variabel independen dalam model regresi. (Ghozali, 2016).

\section{Tabel 2. Hasil dari Uji Multikolonieritas}

\begin{tabular}{|c|l|r|r|}
\hline \multirow{2}{*}{ Model } & \multicolumn{2}{c|}{$\begin{array}{c}\text { Collinearity } \\
\text { Statistics }\end{array}$} \\
\cline { 2 - 4 } & Tolerance & \multicolumn{1}{c|}{ VIF } \\
\hline \multirow{3}{*}{1} & X1_Roe & .825 & 1.212 \\
\cline { 2 - 4 } & X2_Eps & .869 & 1.151 \\
\cline { 2 - 4 } & X3_Inflasi & .539 & 1.854 \\
\cline { 2 - 4 } & $\begin{array}{l}\text { X4_Suku_ } \\
\text { Bunga }\end{array}$ & .513 & 1.950 \\
\hline \multicolumn{2}{|c|}{ a. Dependent Variable:_Harga_Saham } \\
\hline
\end{tabular}

Melihat tabel 2 diatas, angka dari tolerance variabel ROE senilai 0,825 dan angka dari VIF senilai 1,212. Angka dari tolerance variabel EPS senilai 0,869 dan angka dari VIF senilai 1,151. Angka dari tolerance variabel Inflasi senilai 0,539 dan angka dari VIF senilai 1,854. Sedangkan angka dari tolerance variabel Suku bunga senilai 0,513 dan angka dari VIF senilai 1,950. Sehingga berarti tidak berhubungan langsung dengan variabel independen atau tidak memiliki gejala multikolinearitas.

\section{Uji Heteroskedastisitas}

Uji heteroskedastisitas berfungsi untuk menguji terjadi atau tidaknya ketidak samaan variance dari residual satu pengamatan ke pengamatan yang lain dalam model regresi (Ghozali, 2016). Hasil uji heteroskedastisitas dalam penelitian ini dapat dilihat pada tabel dibawah ini:

Tabel 3. Hasil dari Uji Heteroskedastisitas

\begin{tabular}{|l|l|r|r|}
\hline \multirow{2}{*}{ Model } & \multicolumn{2}{|c|}{$\begin{array}{c}\text { Standardized } \\
\text { Coefficients }\end{array}$} \\
\cline { 2 - 4 } \multirow{2}{*}{1} & \multicolumn{1}{|c|}{ t } & \multicolumn{1}{c|}{ Sig. } \\
\cline { 2 - 4 } & (Constant) & 3.216 & .002 \\
\cline { 2 - 4 } & X1_ROE & .554 & .582 \\
\cline { 2 - 4 } & X2_EPS & 3.184 & .003 \\
\cline { 2 - 4 } & X3_Inflasi & .895 & .376 \\
\cline { 2 - 4 } & X4_Suku_Bunga & -2.268 & .028 \\
\hline
\end{tabular}

Melihat tabel nomor 4 diatas, dapat dilihat hasil uji heteroskedastisitas menunjukkan bahwa nilai signifikansi masing-masing variabel, ROE sebesar 0,582, EPS sebesar 0,003, Inflasi sebesar 0,376 dan Suku bunga sebesar 0,028 Jadi dapat diasumsikan bahwa model regresi untuk dua variabel tidak memiliki gejala heteroskedastisitas, karena nilai sig $>5 \%$.

\section{Uji Hipotesis}

Uji t

Uji-t berfungsi untuk menunjukkan bagaimana pengaruh variabel independen terhadap variabel dependen (Ghozali, 2016).

Tabel 4. Hasil dari Uji Parsial (Uji t)

\begin{tabular}{|l|l|r|r|}
\hline \multirow{2}{*}{\multicolumn{2}{|c|}{}} & \multicolumn{2}{c|}{$\begin{array}{c}\text { Standardized } \\
\text { Coefficients }\end{array}$} \\
\cline { 2 - 4 } \multicolumn{2}{|c|}{ Model } & \multicolumn{1}{c|}{ t } & \multicolumn{1}{c|}{ Sig. } \\
\hline \multirow{4}{*}{1} & (Constant) & -.511 & .612 \\
\cline { 2 - 4 } & X1_ROE & 2.509 & .016 \\
\cline { 2 - 4 } & X2_EPS & 10.608 & .000 \\
\cline { 2 - 4 } & X3_Inflasi & 1.852 & .071 \\
\cline { 2 - 4 } & X4_Suku_Bunga & -1.200 & .236 \\
\hline
\end{tabular}

a. Dependent Variable: Y_Harga_Saham

Melihat tabel 4 diatas, dapat ditarik beberapa kesimpulan sebagai berikut:

1. Variabel ROE (X1) mempunyai nilai sig sebesar 0,016 < 0,05 maka ditarik simpulan Ho_ditolak dan $\mathrm{Ha}$ diterima, hal ini berarti_terdapat pengaruh yang signifikan secara parsial antara variabel ROE terhadap Harga saham. Jika memakai kriteria kedua dengan t_hitung sebesar 2,509 dan t_tabel 2,014. Hasil diperoleh t_hitung > t_tabel, sehingga dapatsdisimpulkan bahwa ROE secara parsial berpengaruh signifikan terhadap Harga saham. Simpulan terakhir bahwa hipotesis kesatu diterima.

2. Variabel EPS (X2) mempunyai nilai sig sebesar $0,000<0,05$ maka ditarik simpulan Ho ditolak dan Ha diterima, hal ini berarti terdapat pengaruh yang signifikan secarasparsial antara variabel EPS terhadap Harga saham. Jika memakai kriteria kedua dengan $\mathrm{t}$ hitung sebesar 10,608 dan tabel 2,014. Hasil diperoleh tshitung > t tabel, sehingga dapat disimpulkan bahwa EPS secara parsial berpengaruh signifikan terhadap Harga saham. Simpulan terakhir bahwa hipotesis kedua diterima. 
3. Variabel Inflasi (X3) mempunyai nilai sig sebesar 0,071 >0,05 maka ditarik simpulan Ho diterima dan Ha ditolak, hal ini berarti tidak ada pengaruh yang signifikan secara parsial antara variabel Inflasi terhadap Harga saham. Jika menggunakan kriteria kedua dengan t_hitung sebesar 1,852 dan t_tabel 2,014. Hasil_diperoleh t_hitung< t_tabel, sehingga dapat disimpulkan bahwa Inflasi secara parsial tidak berpengaruh signifikan terhadap Harga saham. Simpulan terakhir bahwa hipotesis ketiga ditolak.

4. Variabel Suku bunga (X4) mempunyai nilai sig sebesar 0,236>0,05 maka ditarik simpulan Ho diterima dan_Ha ditolak, hal ini berarti tidak ada pengaruh yang signifikan secara parsial antara variabelsSuku bunga terhadap Harga saham. Kriteria kedua dengan $t$ hitung sebesar -1,200 dan $t$ tabel -2,014. Hasil diperoleh $\mathrm{t}$ hitung $<\mathrm{t}$ tabel, sehingga dapat disimpulkan bahwa suku bunga secara parsial tidak berpengaruh signifikan terhadap Harga saham. Simpulan terakhir bahwa hipotesis keempat ditolak.

\section{Uji F}

Uji-F berfungsi untuk menguji atau menunjukkan implikasi dari semua variabel independen pada variabel yang bergantung pada banyak model regresi linier. (Chandrarin, 2017)

\section{Tabel 5. Hasil dari Uji Simultan (Uji F)}

\begin{tabular}{|l|l|c|c|}
\hline \multicolumn{2}{|l|}{ Model } & $\mathrm{F}$ & Sig. \\
\hline \multirow{3}{*}{1} & Regression & 39.489 & $.000^{\mathrm{b}}$ \\
\cline { 2 - 4 } & Residual & & \\
\cline { 2 - 4 } & Total & & \\
\hline
\end{tabular}

a. Dependent Variable: Y_Harga_Saham

b. Predictors: (Constant), X4_Suku_Bunga, X2_Eps, X1_Roe, X3_Inflasi

Melihat tabel nomor 5 diatas, diperoleh untuk F tabel sebesar 2,579. Nilai F hitung senilai 39,489. dikarenakan nilai $\mathrm{F}$ hitung lebih besar dari $\mathrm{F}$ tabel dan nilai sig $0,000<0,05$ maka dapat ditarik simpulan pula bahwa ROE, EPS, sInflasi dan Suku bunga secara simultan berpengaruh terhadap Harga saham.

\section{Uji Koefisien Determinasi}

Uji koefisien determinasi $\left(\mathrm{R}^{2}\right)$ tujuannya adalah untuk mengukur kemampuan variabel independen untuk menjelaskan variabel relativistik (Chandrarin, 2017). Hasil uji koefisien determinasi dapat dilihat pada tabel dibawah ini:

Tabel 6. Hasil dari Uji Koefisien Determinasi

\begin{tabular}{lrrrr}
\hline Model & $\mathrm{R}$ & $\begin{array}{c}\mathrm{R} \\
\text { Square }\end{array}$ & $\begin{array}{c}\text { Adjusted } \\
\mathrm{R} \text { Square }\end{array}$ & $\begin{array}{r}\text { Std. Error of } \\
\text { the Estimate }\end{array}$ \\
\hline 1 & $.882^{\mathrm{a}}$ & .778 & .759 & 473.059 \\
\hline a. Predictors: (Constant), X4_SUKU_BUNGA, \\
X2_EPS, X1_ROE, X3_INFLASI
\end{tabular}

Melihat tabel nomor 8 diatas, hasil uji koefisien determinasi menunjukkan nilai $\mathrm{R}^{2}$ senilai 0,759 . Ini berarti variabel $\operatorname{ROE}(\mathrm{X} 1)$, EPS (X2), Inflasi (X3) dan Suku bunga (X4) dalam model regresi sebesar 75,9\%. Jadi pengaruh input dari variabel independen senilai $75,9 \%$ sedangkan sisanya senilai $24,1 \%$ dipengaruhi oleh faktor-faktor lain tidak diteliti dalam penelitian ini.

\section{Pengaruh ROE Terhadap Harga Saham}

Dalam hipotesis kesatu, ada pengaruh yang sig antara variabel ROE pada Harga Saham. Hasil uji t menunjukkansbahwa nilai t hitung sebesars 2,509>t tabel sebesars_2,014 dan nilai signifikan sebesar $0,016<0,05$ sehingga dapat disimpulkan bahwa hipotesis pertama (H1) dalam penelitian ini berpengaruh signifikan secara positif terhadap harga saham di manufaktur sektor consumer goods industry yang terdaftar di Bursa Efek Indonesia tahun 2013-2017 dinyatakan diterima. Hasil penelitian ini konsisten dengan penelitian sebelumnya (Dewi \& Artini, 2016) Yang menunjukkan bahwa ROE memiliki dampak positif pada harga saham. Ini menunjukkan bahwa peningkatan ROE akan berdampak pada peningkatan nilai saham. Tetapi itu tidak cocok dengan hasil penelitian sebelumnya (Egam et al., 2017) yang menyatakan ROE tanpa berdampak material pada harga saham. Ini karena rasio lebih ditekankan pada kinerja keuangan internal perusahaan, tanpa faktor eksternal dari perusahaan. Selain itu, ROE tidak mengungkapkan situasi aktual ketika inflasi terjadi, karena jumlah modal tidak terpengaruh sehingga tidak bisa dibandingkan dengan tahun sebelumnya. 


\section{Pengaruh EPS Terhadap Harga Saham}

Dalam hipotesis kedua, ada pengaruh yang sig antara variabel EPS pada Harga Saham. Hasil uji $\mathrm{t}$ menunjukkan bahwa nilai $\mathrm{t}$ hitung sebesar 10,608 > t tabel sebesar 2,014 dan nilai signifikan sebesar $0,000<0,05$ sehingga dapat disimpulkan bahwa hipotesis kedua (H2) dalam penelitian ini EPS berpengaruh signifikan secara positif terhadap harga saham di manufaktur sektor consumer goods industry yang terdaftar di Bursa Efek Indonesia tahun 2013-2017 dinyatakan diterima. Hasil penelitian ini konsisten dengan peneliti sebelumnya (Watung \& Ilat, 2015) yang menyatakan bahwa EPS memiliki dampak signifikan terhadap harga saham. Ini menunjukkan bahwa pertumbuhan EPS dapat memengaruhi volatilitas harga saham, sehingga investor harus memperhatikan laba perusahaan per saham. Tetapi itu tidak cocok dengan hasil peneliti sebelumnya oleh (Widiastuti et al., 2016) yang menyatakan bahwa EPS tidak memiliki dampak material pada harga saham. Ini karena rasio lebih ditekankan pada kinerja keuangan internal perusahaan. Selain itu, EPS tidak mengungkapkan situasi aktual akibat inflasi dan fluktuasi suku bunga.

\section{Pengaruh Inflasi Terhadap Harga Saham}

Dalam hipotesis ketiga, tidak ada pengaruh yang sig_antara variabel inflasi terhadapsharga saham. Hasil uji t_menunjukkan bahwa nilaist hitung sebesar 1,852<t tabel sebesar 2,014 dan nilai signifikan sebesar $0,071>0,05$ sehingga dapat disimpulkan bahwa hipotesis ketiga (H3) dalam penelitian ini inflasi tidak berpengaruh signifikan secara positif terhadap harga saham di manufaktur sektor consumer goods industry yang terdaftar di Bursa Efek Indonesia tahun 2013-2017 dinyatakan ditolak. Hasil penelitian ini_konsisten dengan peneliti sebelumnya (Dewi \& Artini, 2016) Menunjukkan bahwa inflasi parsial tidak memiliki dampak signifikan terhadap harga saham. Ini menunjukkan bahwa kenaikan inflasi adalah tanda negatif bagi investor karena akan meningkatkan pendapatan dan pengeluaran perusahaan, sehingga investor akan berpikiran ganda berinvestasi dalam persediaan dan menurunkan harga saham. Tetapi tidak cocok dengan hasil peneliti sebelumnya (Putu, 2013) dan (Ningsih \& Waspada, 2018) yang menunjukkan bahwa inflasi memiliki dampak signifikan terhadap harga saham. Ini karena inflasisyang terjadi selama periode penelitian tidak tinggi.

\section{Pengaruh Suku Bunga terhadap Harga Saham}

Dalam hipotesis keempat, tidak ada pengaruh yang sig antara variabel suku bunga terhadap harga saham. Hasil uji t menunjukkan bahwa nilai $\mathrm{t}$ hitung sebesars $-1,200<\mathrm{t}$ tabel sebesar -2,014 dan_nilai signifikan sebesar $0,236>0,05$ sehingga dapat disimpulkan bahwa hipotesis keempat (H4) dalam penelitian ini suku bunga tidak berpengaruh signifikan secara negatif terhadap harga saham di manufaktur sektor consumer goods industry yang terdaftar di Bursa Efek Indonesia tahun 2013-2017_dinyatakan ditolak. Hasil penelitian ini konsisten dengan hasil peneliti sebelumnya (Nainggolan, Khairunnisa, \& Dillak, 2017) yang menyatakan suku bunga tanpa berdampak material pada harga saham. Ini karena jenis investasi di Indonesia sebagai investor yang sering menjalankan ekuitas jangka pendek, sehingga mereka cenderung beroperasi untuk mendapatkan pengembalian yang tinggi di pasar modal dibandingkan dengan investasi pada kurs. Minat. Namun tidak cocok dengan hasil peneliti sebelumnya (Widiastuti et al., 2016) yang mengatakan suku bunga parsial memiliki dampak signifikan terhadap harga saham. Ini menunjukkan bahwa suku bunga dapatsdigunakan sebagai referensi investor untuk memberikan penilaian terhadap nilai saham.

\section{Pengaruh Returnson Equity, Earning per Share, Inflasi dan Suku Bunga terhadap Harga Saham}

Dalam hipotesis kelima, ada pengaruh yang sig antara ROE, EPS, inflasi dan suku bunga secara simultan terhadap harga saham. Berdasarkan hasil uji F (simultan) menunjukkan bahwa nilai_F hitung sebesar $39,489>$ F tabel sebesar 2,579 dan stingkat signifikan Fssebesar 0,000 $<0,05$ hasil uji ini menunjukkan bahwa Ho ditolak dan $\mathrm{Ha}$ diterima sehingga dapat disimpulkan bahwa hipotesis kelima (H5) dalam penelitian ini 
return on equity, earning per share, inflasi dan suku bunga berpengaruh signifikan secara simultan terhadap harga saham di manufaktur sektor consumer goods industry yang terdaftar di Bursa Efek Indonesia tahun 2013-2017 dinyatakan diterima. Hasil penelitian ini sejalan dengan hasil peneliti sebelumnya (Widiastuti et al., 2016) yang menyatakan bahwa ROE, EPS, Inflasi dan suku bunga secara simultan memiliki dampak signifikan pada harga saham. Ini menunjukkan bahwa manajemen dalam manajemen perusahaan dan investor dapat menghasilkan ROE, EPS, inflasi, dan suku bunga sebagai referensi dalam penilaian harga saham dan pengaturan strategi pendanaan sehingga keuntungan dapat dibuat.

\section{KESIMPULAN DAN SARAN}

Berdasarkan hasil dan pembahasan yang telah dijabarkan sebelumnya, maka dapat ditarik beberapa kesimpulan sebagai berikut:

1. ROE berpengaruh secara positif dan signifikan terhadap harga saham dengan nilai t hitung sebesar 2,509 > t tabel sebesar 2,014 dan nilai signifikan sebesar 0,016 < 0,05 .

2. EPS berpengaruh secara positif dan signifikan terhadap harga saham dengan nilai $\mathrm{t}$ hitung sebesar $10,608>\mathrm{t}$ tabel sebesar 2,014 dan nilai signifikan sebesar $0,000<\mathrm{s} 0,05$.

3. Inflasi tidak berpengaruh secara positif dan tidak signifikan terhadap harga saham dengan nilai $t$ hitung sebesars 1,852 < t tabel sebesar 2,014 dan nilai signifikan sebesar $0,071>0,05$.

4. Suku bunga tidak berpengaruh secara negatif dan tidak signifikan terhadap harga saham dengan nilai t hitungssebesar $-1,200$ $<\mathrm{t}$ tabel sebesar -2,014 dan nilai signifikan sebesar 0,236>0,05.

5. ROE, EPS, Inflasi dan Suku bunga secara bersamaan mempunyai dampak positif dan signifikan terhadap harga saham dengan nilai $\mathrm{F}$ hitung sebesar $39,489>\mathrm{F}$ tabel sebesar 2,579 dan tingkat signifikan $\mathrm{F}$ sebesar $0,000<0,05$.

\section{DAFTAR PUSTAKA}

Arifin, J. (2018). SPSS 24 Untuk Penelitian dan Skripsi (Edisi 2). Jakarta: PT. Elex Media Komputindo.

Boediono. (2014). Ekonomi Moneter. Yogyakarta: BPPE.

Chandrarin, G. (2017). Metode Riset Akuntansi Pendekatan Kuantitatif. (A. Suslia, Ed.) (Edisi kesa). Jakarta: Salemba Empat.

Chotimah, H., Susilo, H., Henie, M., \& Al, I. (2017). The Factors Which Influence Stock Return with Stock Price as Moderating Variable in Automotive Companies Listed in the Indonesia Stock Exchange. International Journal of Research \& Review, 6-13. https://doi.org/10.1107/s01087681090110 57

David, K. (2010). Pendekatan Teknikal dan Fundamental Untuk Analisis Saham. Manajemen Investasi (Edisi 1). Yogyakarta: Graha Ilmu.

Dewi, A. D. I. R., \& Artini, L. G. S. A. (2016). Pengaruh Suku Bunga SBI, Inflasi, Dan Fundamental Perusahaan Terhadap Harga Saham Indeks LQ-45 Di BEI. E-Jurnal Manajemen Unud, 5(4), 2484-2510.

Dwi, K., Wijayanti, D., Sulasmiyati, S., Administrasi, F. I., \& Brawijaya, U. (2016). Pengaruh Faktor Internal Dan Eksternal Perusahaan Terhadap Harga Saham (Studi pada Perusahaan Sektor Pertambangan yang Terdaftar di Daftar Efek Syariah Periode 2013- 2016 ), 55(2).

Efferin, S., Darmadji, H. S., \& Tan, Y. (2008). Metode Penelitian Akuntansi (Edisi 1). Yogyakarta: Graha Ilmu.

Egam, G. E. Y., Ilat, V., \& Pangerapan, S. (2017). Pengaruh Return On Asset (ROA), Return On Equity (ROE), Net Profit Margin (NPM), Dan Earning Per Share (EPS) Terhadap Harga Saham Perusahaan Yang Tergabung Dalam Indeks LQ45 Di Bursa Efek Indonesia Periode Tahun 2013-2015. Jurnal EMBA, 5(1), 105-114.

Fahmi, I. (2015a). Manajemen Investasi. (M. Muhamad, Ed.) (Edisi 2). Bandung: Salemba Empat.

Fahmi, I. (2015b). Manajemen Investasi. (M. Masykur, Ed.) (2nd ed.). Bandung: Salemba Empat. 
Fahmi, I. (2015c). Pengantar Teori Portofolio Dan Analisis Investasi. (S. Idris, Ed.) (Kesatu). Bandung: Alfabeta.

Ghozali, I. (2016). Aplikasi Analisis Multivariete dengan program IBM SPSS 23. (Prayogo, Ed.) (Edisi 8). SEMARANG: Badan Penerbit Universitas Dipoegoro.

Gusti, D. S. rencana ketut ayu, \& Vijaya, P. D. (2017). Investasi Dan Pasar Modal Indonesia (Cetakan ke). Depok: PT Rajagrafindo Persada.

Nainggolan, F. G., Khairunnisa, \& Dillak, J. V. (2017). Pengaruh Tingkat Inflasi, Suku Bunga dan Nilai Tukar terhadap Harga Saham (Studi kasus pada Perusahaan Sektor Manufaktur yang terdaftar di Bursa Efek Indonesia periode 2005-2014), 4(3), 2838-2843.
Ningsih, M. M., \& Waspada, I. (2018). Pengaruh Bi Rate Dan Inflasi Terhadap Indeks Harga Saham Gabungan (Studi Pada Indeks Properti , Real Estate, Dan Building Construction, di BEI Periode $2013-2017$.

Putu, W. G. (2013). Pengaruh Inflasi, Nilai Tukar Rupiah, Suku Bunga SBI pada Indeks Harga Saham Gabungan di BEI. Jurnal Akuansi Universitas Udaya, 2(1), 421-435.

Widiastuti, S. A., Yunita, I., \& Gustyana, T. T. (2016). Analisis Faktor Internal Dan Eksternal Serta Pengaruhnya Terhadap Harga Saham Pada Perusahaan Pertambangan Yang Terdaftar Di Bursa Efek Indonesia Periode 2010 - 2014 Analysis of Internal and External Factors and Effect on Share Price on Mining Companies L, 3(1), 27-34. 